\title{
ВПЛИВ ВІТАМІНІВ С ТА Е НА АКТИВНІСТЬ NО-СИНТАЗНОЇ СИСТЕМИ В ПІДШЛУНКОВІЙ ЗАЛОЗІ ЩУРІВ НА ТЛІ БЛОКУВАННЯ ЦИКЛООКСИГЕНАЗИ-2 ЗА УМОВ АДРЕНАЛІНІНДУКОВАНОГО СТРЕСУ
}

Досліджено вплив вітамінів C та E на активність NO-синтазної системи в підшлунковій залозі щурів на тлі блокування циклооксигенази-2 за умов адреналініндукованого стресу (АІС). Встановлено, що АІС у тканині підшлункової залози спричинював розвиток нітрозо-оксидативного стресу, про що свідчили підвищення загальної активності NO-синтаз, iNOS і вмісту нітрит-аніона, зниження концентрації L-аргініну в плазмі крові. Введення вітаміну C на тлі AlC знижувало загальну активність NOS за рахунок суттєвого зменшення активності іNOS, тоді як вітамін Е гальмував активність обох ізоформ цього ферменту. Вплив кожного з досліджуваних вітамінів на активність NOS при AIC підсилювався за умов поєднаного введення з блокатором циклооксигенази-2 целекоксибом, проте сумації ефектів не спостерігали.

КЛЮЧОВІ СЛОВА: підшлункова залоза, стрес, NO-синтази, циклооксигеназа-2, вітаміни С та E.

ВСТУП. Стрес є одним із чинників, що викликають розвиток функціональних порушень підшлункової залози (ПЗ), які можуть лежати в основі виникнення панкреатиту. Ці зміни зумовлені активуванням оксидативних процесів і прозапальних ферментів - індуцибельної NOсинтази (iNOS) та циклооксигенази-2 (ЦОГ-2) (рис.). Внаслідок гіпоксії посилюється експресія iNOS та суттєво зростає синтез нітрогену оксиду (NO), який слугує джерелом утворення вільних радикалів (нітроксилу (NO-), пероксинітриту (ONOO-) тощо), що викликають нітрування цитоплазматичних білків і ДНК та, як наслідок, ураження клітин [14, 21].

Експресія ЦОГ-2 спричинює різке підвищення продукції простагландинів (ПГ) (переважно ПГЕ ${ }_{2}$ ), які беруть участь у деструкції панкреатоцитів, посиленні проникності судин, механізмі формування болю тощо $[5,8]$. Між системами NO-синтази/NO та ЦОГ-2/ПГЕ існує тісний функціональний взаємозв'язок [9, 12, 13, 15]. Окрім активації оксидативних процесів, стрес змінює активність ферментів системи антиоксидантного захисту і вміст вітамінів-антиоксидантів (C та E) [3]. Проте вплив останніх на активність NO-синтазної системи в ПЗ щурів на тлі блокування ЦОГ-2 при адреналініндукованому стресі (AIC) вивчено недостатньо.

( О. Я. Скляров, Т. І. Бондарчук, 2015.
У зв'язку з цим, метою даної роботи було дослідити вплив вітамінів C та E на активність системи L-аргінін/NOS/NO у тканині ПЗ щурів на тлі блокування ЦОГ-2 целекоксибом за умов AIC.

МЕТОДИ ДОСЛІДЖЕННЯ. Дослідження проведено на 70 білих безпородних щурахсамцях масою 180-240 г і виконано відповідно до правил, передбачених Європейською комісією з нагляду за проведенням лабораторних досліджень з участю експериментальних тварин. Щурів утримували на стандартному раціоні віварію. У день проведення досліду тварин не годували, забезпечуючи безперешкодний доступ до води.

Експериментальних тварин було поділено на сім груп: 1-ша - інтактні (контроль); 2-га тварини, в яких моделювали стрес шляхом введення адреналіну (натще у дозі 2 мг/кг внутрішньочеревно) [1]; 3-тя - щури, яким на тлі дії адреналіну вводили целекоксиб (“Артеріум", Україна) (перорально в дозі 10 мг/кг); 4-та - щури, яким на тлі дії адреналіну вводили вітамін С (ТОВ “Фармацевтична компанія “Здоров'я", м. Харків, Україна) (внутрішньочеревно у дозі 200 мг/кг) [19]; 5-та - щури, яким на тлі дії адреналіну одночасно вводили целекоксиб і вітамін С у вищевказаних дозах; 6-та - щури, яким на тлі дії адреналіну вводили вітамін E ( $\alpha$-токоферол, "Sigma”, США) (внут- 


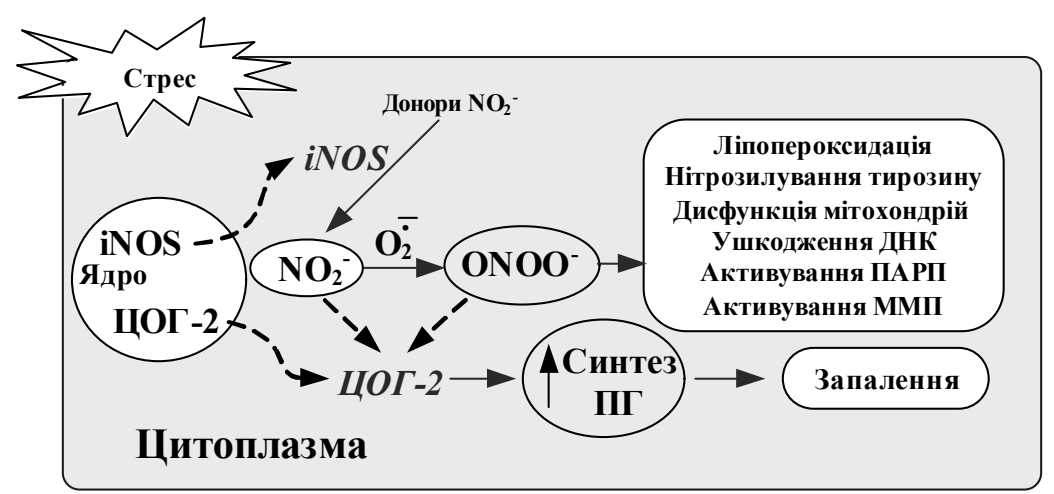

Рис. Роль iNOS і ЦОГ-2 у виникненні деструктивних змін у клітині у відповідь на стрес.

рішньом'язово у дозі 150 мг/кг) [6]; 7-ма щури, яким на тлі дії адреналіну одночасно вводили вітамін Е та целекоксиб у вищевказаних дозах. Препарати вводили за півгодини до ін'єкції адреналіну. Через 24 год після введення адреналіну під тіопенталовим знеболюванням (40 мг/кг) тварин декапітували, проводили розтин по білій лінії живота та виділяли ПЗ, промивали ї̈ фізіологічним розчином і гомогенізували. У гомогенатах досліджували активність NOS та вміст нітрит-аніона $\left(\mathrm{NO}_{2}^{-}\right)$[18]. У плазмі крові визначали концентрацію L-аргініну. Результати опрацьовано методом варіаційної статистики з використанням програмного забезпечення ANOVA з визначенням t-критерію Стьюдента.

РЕЗУЛЬТАТИ Й ОБГОВОРЕННЯ. АДреНалініндукований стрес суттєво змінював показники системи L-аргінін/NOS/NO: загальна активність NOS зросла у 3 рази $(p<0,01)$, активність iNOS підвищилась у 8 разів $(p<0,01)$, a cNOS - на $31 \%(p>0,05)$ порівняно з показниками тварин контрольної групи (табл.).

Вміст $\mathrm{NO}_{2}^{-}$у тканині ПЗ зріс на $26 \%$ $(p<0,05)$, за цих умов концентрація L-аргініну в плазмі крові знизилася на $30 \%(p<0,05)$. Ці результати збігаються з даними літератури і свідчать про виникнення нітрозо-оксидативного стресу, що лежить в основі розвитку деструктивних змін ПЗ під час стресу [16].

Порівняно з показниками тварин контрольної групи введення целекоксибу на тлі AIC y тканині ПЗ призводило до зниження загальної активності NOS на $30 \%(p<0,05)$, активність iNOS при цьому зменшилася на $48 \%(p<0,05)$, відзначали тенденцію до зниження вмісту $\mathrm{NO}_{2}^{-}$ та підвищення - концентрації L-аргініну в плазмі крові. Отже, виражене зниження активності iNOS внаслідок селективного інгібування ЦОГ-2 підтверджує дані літератури щодо ролі ПГ, які синтезуються 3 участю ЦОГ-2, у регуляції активності iNOS. Так, у слизовій оболонці (CO) шлунка донори $\mathrm{NO}_{2}^{-}$посилюють активність ЦОГ, тоді як інгібітори NOS блокують продукування ПГЕ ${ }_{2}$ [19]. Інші автори показали, що блокування активності ЦОГ-2 різними інгібіторами (рофекоксибом, німесулідом, целекоксибом) призводить до зменшення ступеня ушкоджень не лише при гострому панкреатиті, а й при ульцерогенному коліті, знижуючи нейтрофільну інфільтрацію СО товстої кишки, вміст ейкозаноїдів, повертаючи до нормального рівня експресію ЦОГ-1 $[11,17,20]$.

Таблиця - Вплив вітамінів C та E на активність NO-синтазної системи в тканині підшлункової залози щурів на тлі блокування цОГ-2 при АIC (M $\pm \mathrm{m})$

\begin{tabular}{||l|c|c|c|c|c|}
\hline \hline $\begin{array}{c}\text { Група тварин } \\
(\mathrm{n}=10)\end{array}$ & $\begin{array}{c}\text { NOS, } \\
\text { нмоль/хв·г } \\
\text { білка }\end{array}$ & $\begin{array}{c}\text { cNOS, } \\
\text { нмоль/хв·г } \\
\text { білка }\end{array}$ & $\begin{array}{c}\text { iNOS, } \\
\text { нмоль/хв·г } \\
\text { білка }\end{array}$ & $\begin{array}{c}\text { Нітрит-аніон, } \\
\text { мкмоль/л }\end{array}$ & $\begin{array}{c}\text { L-аргінін, } \\
\text { мкг/мл }\end{array}$ \\
\hline Контроль & $0,69 \pm 0,17$ & $0,51 \pm 0,09$ & $0,18 \pm 0,1$ & $17,8 \pm 0,78$ & $38,1 \pm 3,07$ \\
\hline АД & $2,07 \pm 0,15^{\star \star}$ & $0,67 \pm 0,1$ & $1,4 \pm 0,19^{\star *}$ & $22,5 \pm 1,6^{*}$ & $26,6 \pm 3,42^{\star}$ \\
\hline Цел.+АД & $1,44 \pm 0,16^{\#}$ & $0,57 \pm 0,14$ & $0,73 \pm 0,12^{\# \#}$ & $20,7 \pm 1,58$ & $32,1 \pm 1,34^{\#}$ \\
\hline Віт. С+АД & $1,53 \pm 0,13^{\#}$ & $0,66 \pm 0,21$ & $0,91 \pm 0,11^{\#}$ & $18 \pm 2,16$ & $35,2 \pm 2,2^{\# \#}$ \\
\hline Віт. С+Цел.+АД & $1,03 \pm 0,09^{\# \#}$ & $0,37 \pm 0,15^{\#}$ & $0,67 \pm 0,09^{\# \#}$ & $18,8 \pm 1,3$ & $33,1 \pm 3,69^{\#}$ \\
\hline \hline Віт. Е+АД & $1,33 \pm 0,29^{\#}$ & $0,38 \pm 0,18^{\#}$ & $0,94 \pm 0,19^{\# \#}$ & $18,9 \pm 1,57$ & $33,2 \pm 7,9$ \\
\hline Віт. Е+Цел.+АД & $1,14 \pm 0,09^{\# \#}$ & $0,57 \pm 0,06$ & $0,57 \pm 0,05^{\# \#}$ & $18,3 \pm 2,73$ & $32,4 \pm 5,83$ \\
\hline \hline
\end{tabular}

Примітки:

1. * - $p<0,05 ;{ }^{* *}-p<0,01$ порівняно з показниками тварин контрольної групи.

2. \# - p<0,05; \#\# - p<0,01 порівняно з показниками при AIC.

3. АД - адреналін; Цел. - целекоксиб; Віт. - вітамін. 
Інгібування активності ЦОГ-2 на тлі дії вітаміну С знижувало загальну активність NOS на $50 \%(p<0,01)$ порівняно з введенням адреналіну, на $33 \%(p<0,01)$ - порівняно 3 дією вітаміну C та на $28 \%(p<0,05)$ - порівняно із самостійним впливом целекоксибу. Активність iNOS була вдвічі $(p<0,01)$ меншою порівняно 3 введенням адреналіну і на $26 \%(p<0,05)$ порівняно із самостійним впливом вітаміну С. У дослідженнях з вивчення впливу вітаміну С на тлі дії неселективного блокатора ЦОГ-1/ ЦОГ-2 аспірину на СО шлунка було продемонстровано, що цей вітамін проявляє цитопротекторний ефект не лише шляхом активування експресії mRNA антиоксидантних ензимів супероксиддисмутази, глутатіонпероксидази та каталази, а й знижуючи експресію iNOS i двох ключових прозапальних цитокінів - інтерлейкіну- $1 \beta$ та фактора некрозу пухлин- $\alpha[7,10]$.

Слід зауважити, що за цих умов спостерігали значне зниження cNOS: на $45 \%(p<0,05)$ порівняно з введенням адреналіну та із самостійною дією вітаміну C, на $35 \%(p<0,05)$ порівняно з дією целекоксибу на тлі АІС. Вміст $\mathrm{NO}_{2}^{-}$у тканині ПЗ і концентрація L-аргініну в плазмі крові залишалися на рівні показників самостійної дії вітаміну С. Отримані результати свідчать про те, що вітамін С у поєднанні 3 целекоксибом не тільки проявляв антиоксидантний вплив, а також зменшував загальну активність NOS. Поєднане застосування вітаміну С і селективного блокатора ЦОГ-2 на тлі AIC мало більш виражений протизапальний ефект порівняно із самостійною дією вказаних речовин, що проявлялося зниженням активHоCTi iNOS.

Поєднана дія вітаміну E та целекоксибу на тлі AIC на 55 \% ( $<<0,01)$ знижувала загальну активність NOS порівняно з введенням адреналіну, тоді як самостійний вплив цих речовин спричинював лише тенденцію до зменшення загальної активності NOS. Активність iNOS знизилася за таких умов на $60 \%(p<0,01)$ порівняно з введенням адреналіну та на $40 \%$ $(p<0,05)$ - порівняно із самостійним впливом цього вітаміну, тоді як порівняно із самостійною дією целекоксибу вона зменшувалася недостовірно. Слід зауважити, що активність cNOS при цьому повернулася до показників тварин контрольної групи. Вміст $\mathrm{NO}_{2}^{-}$у тканині ПЗ мав тенденцію до зменшення, у плазмі крові концентрація L-аргініну знижувалася недостовірно порівняно з введенням адреналіну, на 22 \% порівняно з введенням целекоксибу та на $25 \%$ - порівняно із самостійною дією вітамінуЕ. Проте при експериментальній виразці шлунка вітамін Е на тлі інгібування ЦОГ-2 суттєво не впливав на активність NOS у CO, але викликав різке зменшення вмісту $\mathrm{NO}_{2}^{-}[2,4]$.

ВИСНОВКИ. 1. Адреналініндукований стрес у тканині ПЗ супроводжувався зростанням загальної активності NO-синтаз, iNOS і вмісту нітрит-аніона, зниженням концентрації L-apгініну в плазмі крові.

2. Інгібування ендогенних ПГ, що синтезуються з участю ЦОГ-2, на тлі AІC зменшувало загальну активність NO-синтаз та iNOS.

3. Введення вітаміну C на тлі AIC знижувало загальну активність NOS за рахунок суттєвого зменшення активності iNOS, тоді як вітамін E гальмував активність обох ізоформ цього ферменту, концентрація нітрит-аніона в тканині ПЗ мала тенденцію до зниження, a L-аргініну в плазмі крові - до зростання.

4. Вплив кожного з досліджуваних вітамінів на активність NOS при AIC був найбільшою мірою виражений при їх поєднаному введенні з блокатором ЦОГ-2 целекоксибом, проте сумації ефектів не спостерігали.

Перспективи подальших досліджень. Потребують поглибленого дослідження самостійна та поєднана дії вітамінів-антиоксидантів (С і Е) на функціональний стан підшлункової залози на тлі водно-іммобілізаційного стресу.

\section{СПИСОК ЛІТЕРАТУРИ}

1. Белостоцкий Н. И. Язвеобразование в слизистой оболочке желудка крыс под влиянием катехоламинов / Н. И. Белостоцкий // Патол. физиол. и эксперим. медицина. - 1988. - № 1. C. 24-27.

2. Вплив вітаміну C на антиоксидантні та цитопротекторні процеси у органах травної системи за умов експериментальної виразки шлунка / І. Б. Грюк,
Н. Р. Шамро, В. С. Журомський [та ін.] // Експерим. та клініч. фізіол. і біохім. - 2010. - № 2 (50). C. $50-56$.

3. Особливості дії вітамінів Е та С у регуляції NO-синтазної системи у слизових оболонках шлунка та товстої кишки за умов стресу / В. С. Журомський, Н. Р. Шамро, І. Б. Грюк [та ін.] // Мед. хімія. - 2009. 11, № 3 (40). - C. 18-20. 
4. Скляров О. Я. Вплив $\alpha$-токоферолу на процеси ліпопероксидації та вміст оксиду азоту в шлунку за умов блокування індуцибельної NO-синтази та циклооксигенази-2 / О. Я. Скляров, В. С. Журомський // Биологически активные вещества: фундаментальные и прикладные вопросы получения и применения : тезисы докл. науч.-практ. конф., Новый Свет, Крым, 25-30 мая 2009 г. - K. : Mavis publ., 2009. - C. 415-416.

5. COX-2 is not required for the development of murine chronic pancreatitis/ A. Silva, A. Weber, M. Bain [et al.] // Am. J. Physiol. Gastrointest Liver Physiol. 2011. - 300. - P. 968-975.

6. Effect of various doses of palm vitamin $E$ and tocopherol on aspirin-induced gastric lesions in rats / K. Jaarin, M. T. Gapor, M. I. Nafeeza, A. M. Fauzee// Int. J. Exp. Pathol. - 2002. - 83, № 6. - P. 295-302.

7. $\mathrm{H}_{2} \mathrm{~S}$-Releasing Aspirin Protects against AspirinInduced Gastric Injury via Reducing Oxidative Stress / L. Liu, J. Cui, Ch.-J. Song [et al.] // PLOS ONE. 2012. - 7, № 9. - P. 46301.

8. Inhibition of cyclooxygenase-2 in experimental severe acute pancreatitis / de J. L. Almeida, J. Jukemura, A. M. Coelho [et al.] // Clinics (Sao Paulo). 2006. - 61, № 4. - P. 301-306.

9. Involvement of cyclooxygenase-derived prostaglandin E2 and nitric oxide in the protection of rat pancreas afforded by low dose of lipopolysaccharide / J. Jaworek, J. Bonior, R. Tomaszewska [et al.] // J. Physiol. Pharmacol. - 2001. - 52 (1). - P. 107-26.

10. Konturek P. C. Effect of vitamin C-releasing acetylsalicylic acid on gastric mucosal damage before and after Helicobacter pylori eradication therapy / P. C. Konturek, J. Kania, U. Gesner // Europ. J. Pharmacol. - 2004. - 506, № 2. - P. 169-177.

11. Martin A. R. The COX-2 inhibitor, rofecoxib, ameliorates dextran sulphate sodium induced colitis in mice / A. R. Martin, I. Villegas, C. Alarcyn de la Lastra // Inflamm. Res. - 2005. - 54, № 4. - P. 145-151.

12. Modulation of prostaglandin biosynthesis by nitric oxide and nitric oxide donors/ V. Mollace, C. Muscoli, E. Masini [et al.] // Pharmacol. Rev. 2005. - 57, № 2. - P. 217-252.
13. Moleclar mechanisms underlying chemopreventive activities of anty-inflammatory phytochemicals: downregulation of COX and iNOS through suppression of NF-kappa B activation / Y. J. Surh, K. S. Chun, H. H. Cha [et al.] // Mutat. Res. - 2001. -480-481. P. 243-268.

14. Pacher $P$. Nitric oxide and peroxynitrite in health and disease / P. Pacher, J. S. Beckman, L. Liaudet // Physiol. Rev. - 2007. - 87 (1). - P. 315-424.

15. Potential role of NO in modulation of COX2 expression and PGE2 production in pancreatic betacells / J. J. Ling, Y. J. Sun, D. Y. Zhu [et al.] // Acta Biochim. Biophys. Sin. (Shanghai). - 2005. - 37 (2). P. 139-46.

16. Role of endogenous nitric oxide in mucosal defense of inflamed rat stomach following iodoacetamide treatment / H. Nishio, Y. Hayashi, S. Terashima, K. Takeuchi // Life Sciences. - 2006. - 79, № 16. P. 1523-1530.

17. Selective cyclooxygenase-2 inhibitor ameliorates cholecystokinin-octapeptide-induced acute pancreatitis in rats / S. Sang-Wan, J. Won-Seok, P. TaiGuang [et al.] // World J. Gastroenterol. - 2007. - 13, № 16. - P. 2298-2304.

18. Sklyarov A. Ya. Role of nitric oxide-synthase and cyclooxygenase/lipooxygenase systems in development of experimental ulcerative colitis / A. Ya. Sklyarov, N. B. Panasyuk, I. S. Fomenko // J. Physiol. Pharmacol. - 2011. - 62 (1). - P. 65-73.

19. The effects of methidathion on lipid peroxidation and some liver enzymes: role of vitamins $\mathrm{E}$ and C / L. Altuntas, N. Delibas, M. Demirci [et al.] // Arch. Toxicol. - 2002. - 76, № 8. - P. 470-473.

20. Wallace J. L. Emerging roles for cyclooxygenase-2 in gastrointestinal mucosal defense / J. L. Wallace, P. R. Devchand // Br. J. Pharmacol. - 2005. 145 (3). - P. 275-282.

21. Zhang L. Effects and mechanism of the selective COX-2 inhibitor, celecoxib, on rat colitis induced by trinitrobenzene sulfonic acid / L. Zhang, Y. M. Lu, X. Y. Dong // Chin. J. Dig. Dis. - 2004. - 5, № 3. - P. 110-114.

А. Я. Скляров, Т. И. Бондарчук ЛЬВОВСКИЙ НАЦИОНАЛЬНЫЙ МЕДИЦИНСКИЙ УНИВЕРСИТЕТ ИМЕНИ ДАНИЛА ГАЛИЦКОГО

\section{ВЛИЯНИЕ ВИТАМИНОВ С И Е НА АКТИВНОСТЬ NО-СИНТАЗНОЙ СИСТЕМЫ В ПОДЖЕЛУДОЧНОЙ ЖЕЛЕЗЕ КРЫС НА ФОНЕ БЛОКИРОВАНИЯ ЦИКЛООКСИГЕНАЗЫ-2 В УСЛОВИЯХ АДРЕНАЛИНИНДУЦИРОВАННОГО CTPECCA}

\section{Резюме}

Исследовано влияние витаминов C и Е на активность NO-синтазной системы в поджелудочной железе крыс на фоне блокирования циклооксигеназы-2 в условиях адреналининдуцированного стресса (АИС). Установлено, что АИС в ткани поджелудочной железы вызывал развитие нитрозо- 
оксидативного стресса, о чем свидетельствовали повышение общей активности NO-cинтаз, iNOS и содержания нитрит-аниона, снижение концентрации L-аргинина в плазме крови. Введение витамина C на фоне AИC снижало общую активность NOS за счет существенного уменьшения активности iNOS, тогда как витамин E тормозил активность обеих изоформ этого фермента. Влияние каждого из исследуемых витаминов на активность NOS при AИC усиливалось в условиях совместного введения с блокатором циклооксигеназы-2 целекоксибом, однако суммации эффектов не наблюдалось.

КЛЮЧЕВЫЕ СЛОВА: поджелудочная железа, стресс, NO-синтазы, циклооксигеназа-2, витамины С и E.

A. Ya. Sklyarov, T. I. Bondarchuk DANYLO HALYTSKY LVIV NATIONAL MEDICAL UNIVERSITY

\section{ACTION OF VITAMINES C AND E ON THE ACTIVITY OF NO-SYNTHASE SYSTEM IN PANCREAS OF RATS ON THE BACKGROUND OF CYCLOOXYGENASE-2 BLOCKAGE AND EPINEPHRIE-INDUCED STRESS}

\section{Summary}

In experiments, the action of vitamins (vit) $C$ and $E$ on the activity of NO-synthase system was investigated in pancreas of rats on the background of cyclooxygenase-2 (COX-2) blockage and epinephrineinduced stress (EIS). It was shown that EIS caused the development of nitroso-oxidative stress in pancreas manifested by the increase of general activity on NO-synthases, iNOS and the content of nitrite-anion accompanied by the decrease of L-arginine concentration in blood plasma. Administration of vit $C$ on the background of EIS, decreased the general activity on NO-synthases mainly by a considerable decrease of iNOS activity, whereas vit E inhibited activities of both isoforms of this enzyme. The action of each of investigated vit on the iNOS activity under condition of EIS was enhanced by the combined action with COX-2 inhibitor celecoxib, however no addition of their effects was noticed.

KEY WORDS: pancreas, stress, NO-synthase, cyclooxygenase-2, vitamins C and E.

Отримано 12.01 .15

Адреса для листування: О. Я. Скляров, Львівський національний медичний університет імені Данила Галицького, вул. Пекарська, 69, Львів, 79010, Україна. 